\title{
Pharmacognostic and Preliminary Phytochemical Investigation of Leaves of Aralia Racemosa L
}

\author{
D S N B K Prasanth ${ }^{1}$, Atla Srinivasa Rao², Rajendra Prasad Yejella ${ }^{3}$ \\ 'Research Scholar, Department of Pharmacy, JNTUK, Kakinada- 533003, Andhra Pradesh,INDIA. \\ 2Department of Pharmaceutical Analysis and Quality Control, Shri Vishnu College of Pharmacy, Bhimavaram, Andhra Pradesh, INDIA. \\ ${ }^{3}$ Department of Pharmaceutical Chemistry, University College of Pharmaceutical Sciences, Visakhapatnam, INDIA.
}

\begin{abstract}
Objective: Ethnomedicinally, the entire plant and its parts are generally utilized by local people for the treatment of different aliment conditions without standardization. The standardization of crude drug is a crucial part of establishing its correct identity. Prior to any crude drug can be included in an herbal pharmacopeia, pharmacognostic and physicochemical parameters and standards to be established. Aralia racemosa L. perennial herb belongs to family Araliaceae. It is commonly known as American Spikenard. It is traditionally used in the treatment of Rheumatism, Whooping cough, skin diseases, pleurisy, diaphoretic, diuretic, pulmonary diseases, asthma, rheumatism, diarrhea, stimulant, expectorant, syphilis, Inflammation and Hay fever. In the view of lack of pharmacognostic study of leaf of Aralia racemosa L. Methods: The macroscopical, microscopical and physicochemical parameters were assessed according to WHO Quality Control Methods for herbal materials. The leaves of Aralia racemosa. $L$ was subjected for successive solvent extraction and preliminary phytochemical screening was carried out, along with florescence analysis of leaf Powder with different reagents were evaluated. Results: Macroscopy of the leaves showed oval to rounded shape with tooted margin, cordate base and pointed tip. Microscopic studies revealed the presence of anisocytic stomata, bicolateral vascular bundles, lignified fibers, spiral vessels and
\end{abstract}

rosette shaped calcium oxalate crystals. Physicochemical parameters such as moisture content, extractive values, ash content and fluorescent behavior of leaf powder were also determined. Preliminary Phytochemical analysis revealed the presence of various phytochemical constituents viz., glycosides, tannins, flavonoids, saponins and steroids. Conclusion: The results of current study could be served as a diagnostic tool for the standardization of this medicinal plant and will helpful in characterization of the crude drug.

Key words: Pharmacognostic, Aralia racemosa, Rosette shaped calcium oxalate crystals, Bicolateral vascular bundles, Anisocytic stomata, lignified fibers

\section{Correspondence:}

Mr. D. S. N. B. K. Prasanth,

M. Pharm, Pharmacognosy,

Department of Pharmacognosy, V. V. Institute of Pharmaceutical Sciences, Gudlavalleru-521356, Andhra Pradesh, INDIA.

Ph no: +917382027437

Email: dsnbkprasanth@gmail.com

DOI : 10.5530/pj.2016.3.13

\section{INTRODUCTION}

Medicinal plants are playing a key part in traditional systems for the remedy of various maladies. However the primary obstacle being used of conventional medicine in the developed nations is absence of proof of documentation and stringent quality control measures. There is need of documentation for the research work carried out on traditional medicines and in this context, with the present upsurge in the phytotherapeutics, the availability of genuine plant material becoming famine. With this disadvantage, there is need to standardize the plants and its parts to be utilized as a medicine. The process of standardization can be acquired by step wise pharmacognostic and phytochemical studies. Proper identification and quality assurance of beginning material is a significant stride to guarantee reproducible quality of herbal medicine which will helps us to affirm its safety and efficacy. ${ }^{1}$

For this reason we have done pharmacognostic investigations of Aralia racemosa. L (A. racemosa). belonging to family Araliaceae in the present study. The genus Aralia of the family Araliaceae is comprised up of 71 species of plants dispersed crossover Asia, North America and South America i.e., A. armata, A. bipinnata, A. chinensis, A. continentalis, A. cordata, A. dasyphylla, A. echinocaulis, A.elata, A. fargensii, A. nudicaulis. One genus of Aralia found in India i.e., Aralia racemosa L. It is commonly known as American Spikenard. The plants of this family have a noteworthy contribution in the treatment of respiratory inflammation, diabetes, cancer, and parasitic infections. ${ }^{2}$ The genus Aralia is rich in triterpenoidal saponins. Phytochemical investigation on Aralia racemosa L. reveals the presence of triterpenoidal saponins i.e., Oleanolic Acid, Sterols i.e., $\beta$-sitosterol and Diterpenoids i.e., ent-Kaurenoic acid, Continentalic acid. ${ }^{2,3}$ In traditional system of medicine the various parts of $A$. racemosa. $\mathrm{L}$ is used in the treatment of Rheumatism, Whooping cough, skin diseases, pleurisy, diaphoretic, diuretic, pulmonary diseases, asthma, rheumatism, diarrhea, stimulant, expectorant, syphilis, Inflammation and Hay fever. ${ }^{4-5}$

Various pharmacological activities of Aralia racemosa have been reported such as antioxidant, antidiabetic ${ }^{6-7}$ antitubercular. ${ }^{8}$ Hence, in this work we make an attempt for standardization of Aralia racemosa L. to study the morphological, anatomical, physicochemical and preliminary phytochemical analysis of leaf was done.

\section{MATERIAL AND METHODS}

\section{Plant material}

Aralia racemosa L. leaves were procured in the month of September 2015, from Sri Venkateswara University, Andhra Pradesh. It was identified and authenticated by K. Madhavachetty, plant taxonomist, Department of botany, Sri Venkateswara University, tirupati, Andhra Pradesh and voucher specimen of the plant (No 1489) was deposited at the herbarium for future reference.

\section{Description of the plant}

The perennial herb attains a height of 2 to 5 feet. Root is large, thick, spicy-aromatic; bark thick, whitish internally. Stem ligneously herba- 
ceous, smooth, bifurcating, much branched and devoid of prickles. Leaves are large, odd pinnately compound, ovate to cordate, doubly serrate, acuminate, slightly down. Inflorescence numerous axillary, compound, racemose panicles. Flowers monoeciously polygamous. Calyx coherent with ovary. Petals are 5 in number and epigynous. Stamens 5, epigynous, situated opposite to calyx; ovules anatropous suspended in each cell, styles 5, closely clustered and sometimes united at the base; stigmas capitellate. Fruit globular, aromatic; embryo minute.

\section{Pharmacognostic evaluation}

\section{Organoleptic evaluation}

Organoleptic characteristics of Aralia racemosa L. was assessed by observing colour, odour, taste, size and shape according to WHO Quality Control methods of herbal medicine. ${ }^{9}$

\section{Microscopic evaluation}

\section{Preparation of sections}

Free handed sections of the leaves were cut into thin sections manually with sharp cutting edge of blade. Then transferred on slides cleared by warming with chloral hydrate, stained with Phloroglucinol and Conc. $\mathrm{HCl}$ and mounted in glycerin. The lignified and cellulosic tissues were recognized by utilizing different staining techniques. ${ }^{10}$

\section{Powder microscopy}

The powder microscopy was performed according to the method of Khandelawal. ${ }^{11}$

\section{Physicochemical Analysis}

Physicochemical parameters such as ash value, moisture content and extractive values were determined according to the procedures mentioned in WHO quality control methods for herbal materials. ${ }^{9}$

\section{Phytochemical Analysis}

The various extracts of Aralia racemosa L. were subjected to qualitative chemical analysis according to literature reported. ${ }^{11,12}$

\section{Preparation of extract}

Leaves of Aralia racemosa were shade dried and powdered. One hundred gram of powdered leaves were subjected to maceration by increasing order of polarity viz chloroform, methanol and water. After $24 \mathrm{~h}$ filtered the extracts and concentrate with the help of rotary evaporator.

\section{Fluorescence analysis of the powdered drug}

The fluorescence examination of the powdered leaves was done by placing dry powdered leaves on a slide and observed by treating with a few drops of different chemical reagents to detect the color changes under UV and Visible light. ${ }^{10,11,13}$

\section{RESULTS}

\section{Pharmacognostic evaluation}

\section{Organoleptic and Microscopic evaluation}

Macroscopically, the fresh leaf of A. racemosa is 6 to $14 \mathrm{~cm}$ long, 2 to $6 \mathrm{~cm}$ wide and petiole 0.1 to $2 \mathrm{~cm}$ in length, compound, alternate, oval to round in shape with serrate margin, subcordate to cordate at base, pinnately reticulate venation, veins $8-9$ on each side, conspicuous on both sides, nearly glabrescent on upper surface and pilose on lower surface, dorsiventral, adaxial surface of leaf is dark green in colour and abaxial surface is pale green in colour (Figure 1).

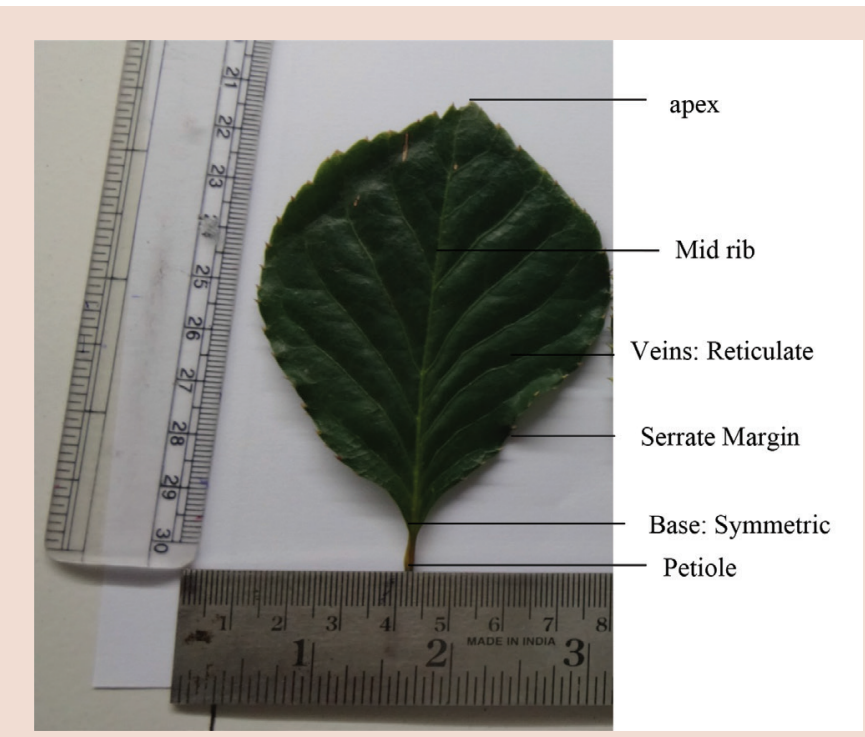

Figure 1: Photograph showing macroscopic characteristics of Aralia racemosa L. Leaf.

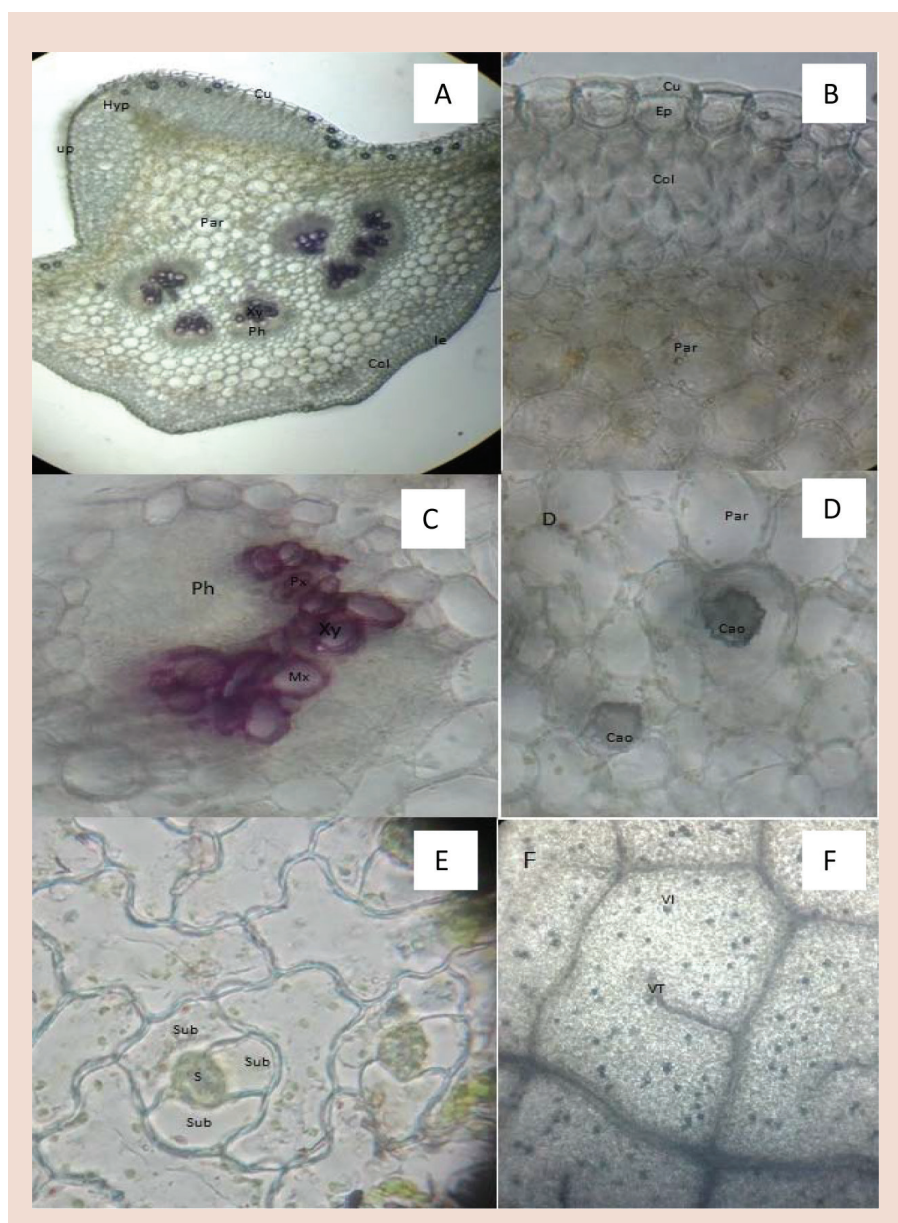

Figure 2: Photograph showing T. S of Leaf passing through midrib portion.

Leaf is dorsiventral with conspicious midrib. TS of leaf passing through midrib region and shows broadly shallow on the adaxial side and convex on the abaxial side (Figure 2). Upper and lower surface of the leaf 

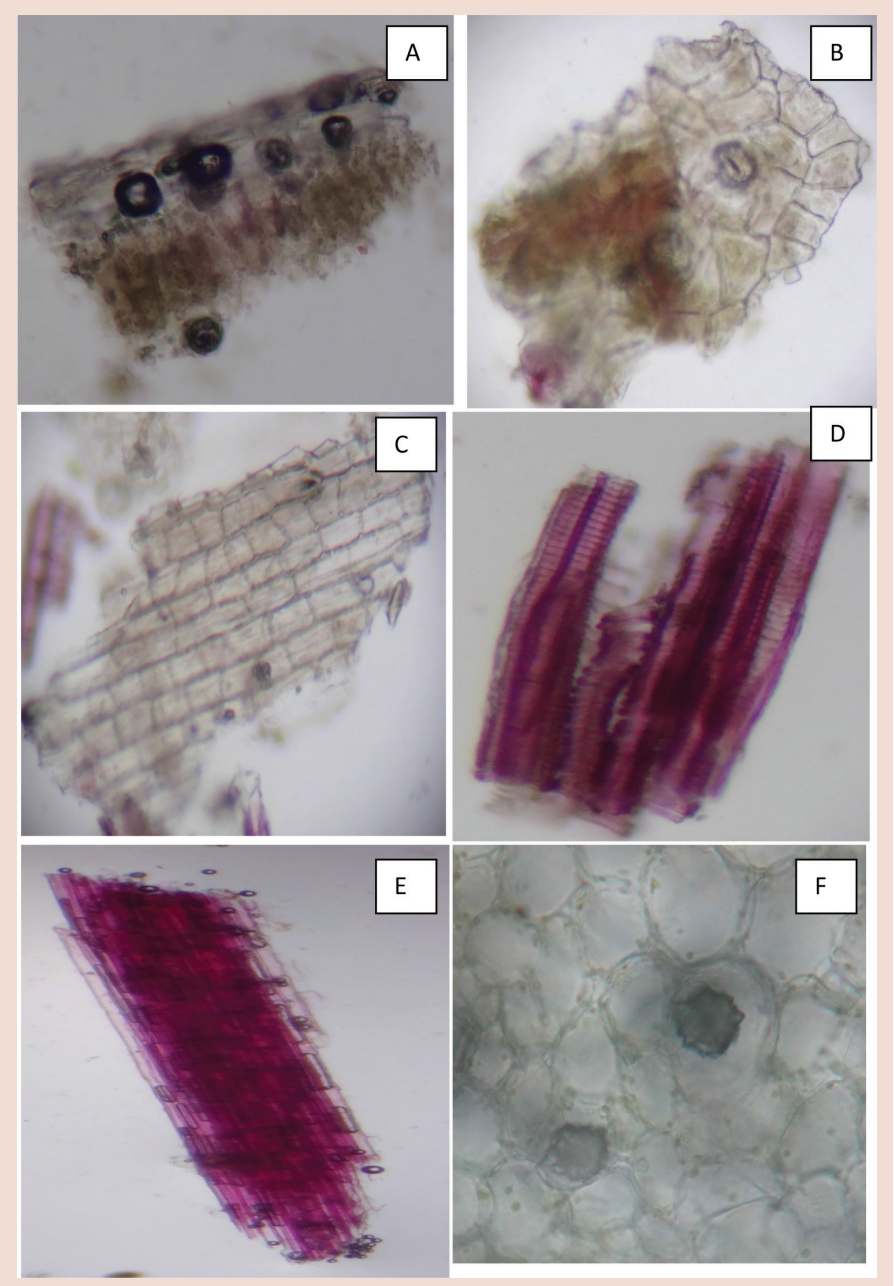

Figure 3: Photograph showing powder characteristics of Leaf.

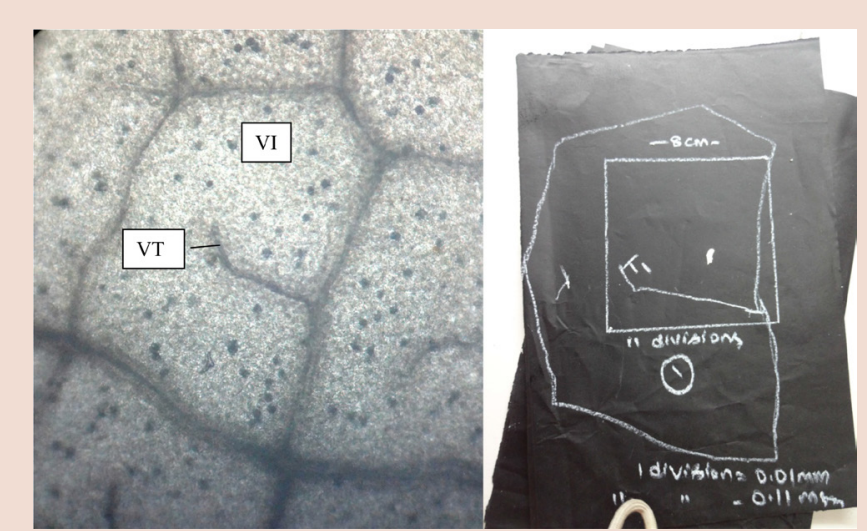

Figure 4: Photograph showing presence of Vein Islet and Vein Termination in surface view of Leaf.

comprises of rectangular thin walled epidermis without intercellular spaces, covered with thick cuticle; followed by 8-10 layered collenchy matous ground tissue underneath upper epidermis and 2-3 layered collenchymatous ground tissue above lower epidermis; midrib region show one median large size vascular bundle and four lateral vascular bundle, which are bicolateral. Xylem is arranged in cup shaped and

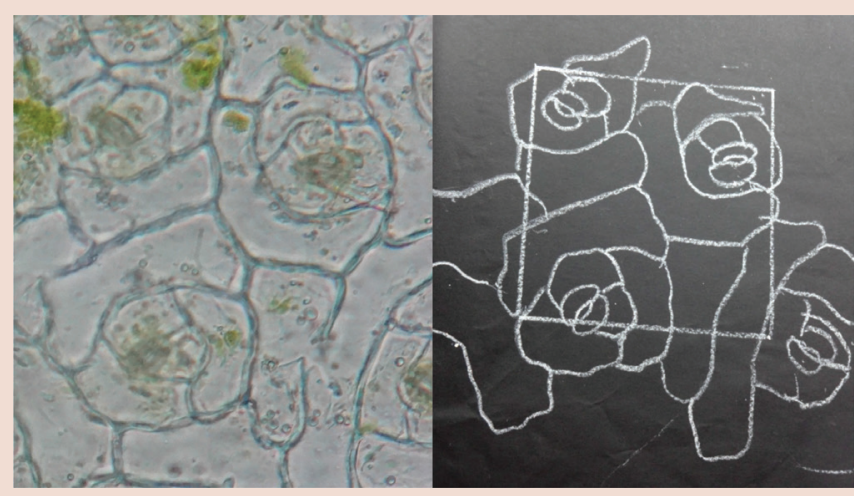

Figure 5: Photograph showing presence of Anisocytic stomata in surface view of Leaf.

\section{Table 1: Quantitative Microscopy of Aralia racemosa}

\begin{tabular}{cc}
\hline Parameters & Values (in $1 \mathrm{~mm}^{2}$ area) \\
\hline Stomatal number upper surface & 58.32 \\
Stomatal number lower surface & 165.28 \\
Stomatal Index upper epidermis & 8.36 \\
Stomatal Index lower epidermis & 25 \\
Vein Islet number & 69.44 \\
\hline
\end{tabular}

Table 2: Physicochemical parameters of leaf powder of Aralia racemosa $L$.

\begin{tabular}{cc}
\hline Parameters & Values \%w/w \\
\hline Moisture content (Loss on drying) & 12 \\
Total ash & 3.26 \\
Acid insoluble ash & 0.063 \\
Water soluble ash & 0.16 \\
Petroleum ether soluble extractive value & 1.5 \\
Chloroform soluble extractive value & 5 \\
Ethyl acetate soluble extractive value & 4 \\
Alcohol soluble extractive value & 11.5 \\
Water soluble extractive value & 15.14 \\
\hline
\end{tabular}

encompassed by phloem confronting toward the lower side. Xylem comprises of vessels, lignified fibers and xylem parenchyma. TS passing through lamina region showed single layered palisade cells followed by several layers of spongy mesophyll embedded with lateral vascular bundles. A. racemosa leaf surface shows the anisocytic stomata (Figure 2) which is characteristic of Family Araliaceae. Leaf surface also shows the presence of veins, vein islets, and vein terminations (Figure 2). Leaf constants such as stomatal number, stomatal index, vein-islet number and veinlet terminations number were measured. The figure and results were shown in Figure 4, 5 and Table 1.

The powder plant material is greenish in color, shows pieces of parenchyma, lignified fibers, bicolateral vascular bundles, palisade cells, pieces of epidermal cells along with anisocytic stomata have shown in Figures 3.

\section{Physicochemical evaluation}

The various physicochemical parameters of leaves and leaf powder i.e., loss on drying, ash value and extractive value are presented in Table 2. 
Table 3: Phytochemical analysis of various extracts of Aralia racemosa L.

\begin{tabular}{ccccc}
\hline Phytoconstituents & Method & Aqueous Extract & $\begin{array}{c}\text { Alcoholic } \\
\text { Extract }\end{array}$ & Chloroform Extract \\
\hline Flavonoids & Shinoda Test & + & + & - \\
& Zn. Hydrocholride test & + & + & - \\
& Lead acetate Test & + & + & - \\
Alkaloids & Wagner Test & - & - & - \\
& Hager's Test & - & + & + \\
Tannins \& Phenols & Fecl Test & + & + & + \\
& Potassium dichromate test & + & + & - \\
Saponins & Foaming Test & + & + & - \\
Terpenoids & Salkowski test & + & - & - \\
Carbohydrates & Molish test & - & - & - \\
Acid compounds & Litmus test & - & + \\
Glycoside & Keller-Killani Test & + & - \\
Amino acids & Ninhydrin test & - & - \\
Proteins & Biuret & - & - \\
\hline
\end{tabular}

- Negative $=$ Absent.

+ Positive $=$ Present.

Table 4: Fluorescence analysis of Aralia racemosa. L

\begin{tabular}{cccc}
\hline Solvent used & Visible light & \multicolumn{2}{c}{ UV light } \\
\cline { 3 - 4 } & & $254 \mathrm{~nm}$ & $366 \mathrm{~nm}$ \\
\hline Distilled water & Green & Green & Green \\
$1 \mathrm{~N} \mathrm{NaOH} \mathrm{1N} \mathrm{Methanol}$ & Green & Dark green & Greenish Black \\
$1 \mathrm{~N} \mathrm{Hcl}$ & Yellowish brown & Yellowish grey & Greenish grey \\
$50 \% \mathrm{HNO}_{3}$ & Yellowish brown & Greenish grey & Dark greenish grey \\
$\mathrm{FeCl}_{3}$ & Pale green & Dark greenish grey & Bluish green \\
$\mathrm{CHCl}_{3}$ & Pale green & Green & Blackish green \\
Picric acid & Brownish yellow & Yellowish green & Light greenish \\
\hline
\end{tabular}

\section{Preliminary Phytochemical Screening}

The preliminary phytochemical screening for the extracts viz., chloroform, ethanol and water was carried out and the results obtained. (Table 3).

\section{Fluorescence analysis}

The behavioral changes of powdered drug with distinctive chemical reagents were determined at both UV and Visible light and it is reported (Table 4).

\section{DISCUSSION}

The evaluation of a crude drug is an indispensable part of establishing the proper identification of a plant material. For this, pharmacognostic and physicochemical parameters must be determined. In this regard, the microscopic and macroscopic features of leaf have been studied. Studies revealed the presence of anisocytic type of stomata, bicolateral vascular bundles and calcium oxalate crystals. Studies of physicochemical parameters can serve as an important source to judge the purity and quality of crude drugs. The extractive values gives the approximate measure of their chemical constituents and from the study, the extractive values of water was highest followed by alcohol. The ash value represents the earthy matter or inorganic components and other impurities present along with drug. The pharmacognostic standard for the leaves of Aralia racemosa L. laid down for the first time in the study. The phytochemical investigation of different solvent extracts viz., chloroform, ethanol and water were examined and it revealed the presence of saponins, tannins, flavonoids, steroids and glycosides.

\section{CONCLUSION}

In this current study, the pharmacognostical investigation, physicochemical parameters, fluorescence analysis and preliminary phytochemical screening of Aralia racemosa L. was carried out. The results of current study could be served as a diagnostic tool for the standardization of this medicinal plant and will helpful in characterization of the crude drug.

\section{ACKNOWLEDGEMENTS}

We extend our sincere thanks to Dr. A. Lakshmana Rao, Principal and management of V. V. Institute of Pharmaceutical Sciences, Gudlavalleru, Andhra Pradesh, for providing the research facilities.

\section{CONFLICT OF INTEREST}

No conflict of Interest. 


\section{ABBREVIATION USED}

UV: Ultraviolet; $\mathbf{H N O}_{3}$ : Nitric acid; $\mathbf{F e c l}_{3}$ : Ferric Chloride; $\mathbf{C H C l}_{3}$ : Chloroform; NaOH: Sodium hydroxide; HCl: Hydrochloric acid; Zn: Zinc.

\section{REFERENCES}

1. Akbar S, Hanif U, Ali J, Ishtiaq S. Pharmacognostic studies of stem, roots and leaves of Malva parviflora L. Asian Pac J Trop Biomed. 2014;4(5):410-5.

2. Clement JA, Clement Ella SH. The Medicinal Chemistry of Genus Aralia. Curr Top Med Chem. 2014;14:2783-801.

3. Clement JA, Flood MJ, Bleich RM, Willis TJ, Kelly RM, Schmitt JD. Diterpenoids and acetylenic lipids from Aralia racemosa. Biochem Sys Ecol. 2013;5:4-7.

4. Quattrocchi umberto. CRC World Dictionary of Medicinal and Poisonous Plants: Common names, scientific names, eponyms, synonyms and etymology. Newyork, London(UK): CRC Press; 2012, p. 353.

5. Duke JA, Bogenschutz-Godwin MJ, du Cellier J, peggy-Ann DK. Handbook of Medicinal Herbs. Raton (US): CRC press; 2002, p. 691
6. Mc Cune LM, Johns T. Antioxidant activity in medicinal plants associated with the symptoms of diabetes mellitus used by the Indigenous Peoples of the North American boreal forest. J Ethnopharmacol. 2002;82(2):197-205.

7. Mc Cune LM, Johns T. Symptom-Specific Antioxidant Activity of Boreal Diabetes Treatments. Pharm Biol. 2003;41(5):362-70.

8. Grange JM, Davey RW. Detection of antituberculous activity in plant extracts. J Appl Bacteriol. 1990;68(6):587-91.

9. WHO. Quality Control Methods for Medicinal Plant Materials. (An authorized publication of World health organization, Geneva). A.I.T.B.S. Publishers and Distributors New Delhi. 2002.

10. Evans WC. Editor. Trease and Evans' Pharmacognosy, $14^{\text {th }}$ ed. London:WB Saunders; 1998. p. 538-547.

11. Khandelawal KR. Practical pharmacognosy. $21^{\text {st }}$ ed. Nirali publication, Pune, India 2008 , p. $25.1-9$

12. Harborne JB. Methods of extraction and isolation. In: Phytochemical methods. Chapman and Hall: London;p.60-66.

13. Gupta PC, Sharma N, Rao ChV. Pharmacognostic studies of the leaves and stem of Careya arborea Roxb. Asian Pac J Trop Biomed. 2012;2(5):404-8.

\section{PICTORIAL ABSTRACT}

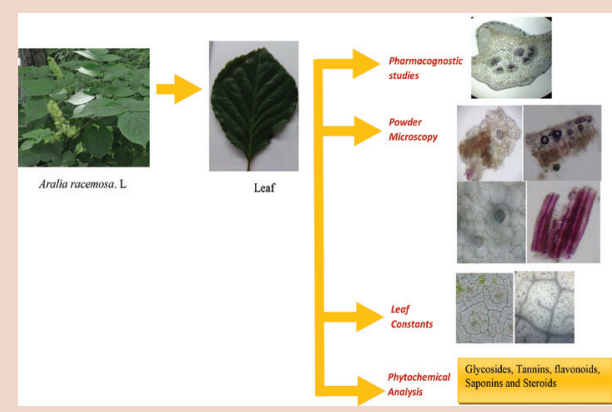

\section{SUMMARY}

- Leaves of Aralia racemosa L. was collected from Sri Venkateswara University, tirupati and authenticated by K. Madhavachetty, plant taxonomist.

- The microscopical evaluation showed the presence of anisocytic stomata, lignified fibers, vessels and rosette shaped calcium oxalate crystals.

- The physical parameters viz., moisture content, extractive values and ash content were assessed wich is helpful for standardization of the crude drug

- The preliminary phytochemical screening of successive solvent extraction of leaves of Aralia racemosa. L shown the presence of glycosides, tannins, flavonoids, saponins and steroids, which can play a vital role in medicine.

\section{ABOUT AUTHORS}

Mr. D S N B K Prasanth: Is a research scholar at the JNTUK. His research is focused on the pharmacognostical findings of Aralia racemosa .L Leaves.

Dr. Atla Srinivasa Rao: Obtained his Ph. D degree in 2009 at Andhra University, Visakhapatnam. Currently he worked as Professor in Shri Vishnu College of Pharmacy, Affliated to Andhra university at Bhimavaram. 